\title{
Tetra-primer ARMS-PCR identified a missense mutation of the bovine NRIP1 gene associated with growth traits
}

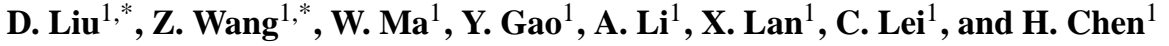 \\ ${ }^{1}$ College of Animal Science and Technology, Northwest A\&F University, Shaanxi Key Laboratory of \\ Molecular Biology for Agriculture, Yangling, Shaanxi 712100, China \\ *These authors contributed equally to this work.
}

Correspondence to: H. Chen (chenhong1212@263.net)

Received: 16 September 2014 - Accepted: 7 April 2015 - Published: 28 April 2015

\begin{abstract}
Nuclear receptor-interacting protein 1 (NRIPI) specifically interacts with the hormone-dependent activation domain AF2 of nuclear receptors to inhibit transcription. Previous work has demonstrated this protein to be a key regulator in modulating transcriptional activity of many transcription factors, some of which are closely related to development and growth. In this study, we have successfully genotyped two newly identified bovine NRIP1 single-nucleotide polymorphisms (SNPs) (c.605A $>\mathrm{G}$ and c.1301G $>\mathrm{A}$ ) using the T-ARMS-PCR method and validated the accuracy by means of PCR-RFLP assay using 1809 individuals of 9 different cattle breeds. The association analyses results indicated that $\mathrm{c} .605 \mathrm{~A}>\mathrm{G}$ locus was significantly associated with body weight and average daily gain in Nanyang cattle at 18 months $(P<0.05)$. Thus it can be inferred that T-ARMSPCR is a rapid, reliable, and cheap method for SNP genotyping and that c.605A $>\mathrm{G}$ polymorphism in bovine NRIPI is associated with growth traits. These findings will be of benefit for the application of DNA markers related to growth traits in marker-assisted selection (MAS), and will improve the promotion of beef cattle.
\end{abstract}

\section{Introduction}

Known as RIP140, nuclear receptor-interacting protein 1 (NRIPI) regulates the expression of clusters of genes in the pathways of glucose uptake, glycolysis, TCA cycle, fatty acid oxidation, and oxidative phosphorylation (Powelka et al., 2006). It also modulates transcriptional repression by nuclear hormone receptors and regulates gene expression in metabolic tissues including the heart (Fritah et al., 2010), skeletal muscle (Seth et al., 2007), and the liver (Herzog et al., 2007). In addition, as a corepressor for nuclear receptors that regulates energy expenditure in adipose tissue, NRIP1 suppresses the expression of metabolic genes involved in glucose and lipid metabolism (Nichol et al., 2006). NRIPl is even essential for female fertility (White et al., 2000).

The expression of NRIP1 is also essential for oocyte release in ovulation (Steel et al., 2005). Moreover, NRIP1 is involved in some human disease processes, like morbid obesity (Catalán et al., 2009) and breast cancer (Docquier et al., 2010).
Although NRIPI has an important role in metabolism, until now there have been no studies on it in cattle. Here, we studied 1809 individuals from 9 different cattle breeds in order to scan the single-nucleotide polymorphisms (SNPs) and developed a sensitive, quick, and low-cost T-ARMS-PCR assay for reliable detection. We also investigated the genetic effects of these polymorphisms on economically valuable growth traits of Nanyang cattle.

\section{Material and methods}

\subsection{Cattle populations, genomic DNA isolation, and data collection}

Genomic DNA samples were obtained from blood samples of 1809 cattle, including Qinchuan (QC, $n=510)$, Nanyang (NY, $n=225$ ), Luxi (LX, $n=183$ ), Jiaxian (JX, $n=410$ ), Chinese Red Steppe cattle (CRS, $n=139)$, Chinese Holstein $(\mathrm{CH}, n=87)$, Angus (AGS, $n=60)$, Hasake (HSK, $n=66$ ), and yak (YAK, $n=83$ ) breeds. These cattle were separately from Shaanxi, Henan, Shandong, Jilin, and Qing- 
Table 1. Primer information for PCR amplification of bovine NRIP1 gene.

\begin{tabular}{llcc}
\hline Loci & Primers $\left(5^{\prime}-3^{\prime}\right)$ & $\begin{array}{l}\text { Fragments } \\
\left(\mathrm{XM} \_603300.3\right)\end{array}$ & AT $\left({ }^{\circ} \mathrm{C}\right)^{*}$ \\
\hline P1 & $\begin{array}{l}\text { F: AAGCCCTCGTGAACACTTCTATTG } \\
\text { R:TGCTGTAAATGGGCTTCACT }\end{array}$ & $860 \mathrm{bp}$ & 56 \\
\hline P2 & $\begin{array}{l}\text { F: CCAAACCCAGTGTTGCCTGTAGC } \\
\text { R: CCAAGCAGCAACTGAAGAAG }\end{array}$ & $742 \mathrm{bp}$ & 56 \\
\hline P3 & $\begin{array}{l}\text { F: ATTCGCACCAGAAAGTAACCCT } \\
\text { R: CTATCTGTATGTTCCTGAGTGC }\end{array}$ & $754 \mathrm{bp}$ & 56 \\
\hline P4 & $\begin{array}{l}\text { F: GGGAAGACTGAAAAGAAAGAGAAG } \\
\text { R: ACTCAAGATCACTTCTGCTAAG }\end{array}$ & $599 \mathrm{bp}$ & 56 \\
\hline P5 & $\begin{array}{l}\text { F: GCTGAAACTTAGCAGAAGTGATCTT } \\
\text { R: GGCAGGTCCATTTTATTCTGATTC }\end{array}$ & $793 \mathrm{bp}$ & 56 \\
\hline
\end{tabular}

* AT: annealing temperature.

hai provinces of China. DNA samples were extracted from $1 \mathrm{~mL}$ of whole blood according to standard procedures (Sambrook and Russell, 2001). Records of growth traits (body weight, body height, body length, heart girth, hucklebone width, average daily gain) at birth, 6 months, 12 months, and 18 months of age for $225 \mathrm{NY}$ cattle were collected for association analysis.

\subsection{SNP discovery}

DNA of 30 randomly chosen individuals from the same breed were mixed into one DNA pool; therefore nine pools from nine different breeds were prepared for PCR amplification. Five pairs of primers (Table 1) were designed to amplify the single exon of the bovine NRIP1 (GenBank accession number XM_603300.3). Each PCR reaction was carried out in a $25 \mu \mathrm{L}$ reaction mixture, and the cycling program was $5 \mathrm{~min}$ at $95^{\circ} \mathrm{C}, 34$ cycles of denaturing at $94^{\circ} \mathrm{C}$ for $30 \mathrm{~s}$, annealing at $56^{\circ} \mathrm{C}$ for $30 \mathrm{~s}$, extension at $72^{\circ} \mathrm{C}$ for $30 \mathrm{~s}$, and a final extension at $72^{\circ} \mathrm{C}$ for $10 \mathrm{~min}$, and subsequently cooling at $4{ }^{\circ} \mathrm{C}$. All PCR products were then sequenced to screen the variations.

\subsection{Genotyping}

Two new polymorphisms (c.605A>G and c. $1301 \mathrm{G}>\mathrm{A}$ ) were found in the NRIP1 gene CDS region; these were used to design the primers for genotyping. The T-ARMS-PCR method utilizes two primer pairs to amplify two different alleles in one PCR reaction (Ye et al., 2001; Rincon and Medrano, 2003), and it does not need enzymes to digest for genotyping. Detailed information of these SNPs and their respective two genotyping approaches is listed in Table 2.

\subsection{Statistical analysis}

Genotypic and allelic frequencies were directly calculated. $\mathrm{He}$ (gene heterozygosity), $\mathrm{Ne}$ (effective allele numbers), and PIC (polymorphism information content) were calculated according to the methods of Nei (1973). SPSS software (version 16.0) was used to evaluate the relationship between genotypes of c.605A $>\mathrm{G}$ and growth traits in the NY population.

The statistical model used as follows:

$Y_{i j k}=\mu+A_{i}+G_{j}+(\mathrm{AG})_{i j}+e_{i j k}$,

where $Y_{i j k}$ is the observation of growth traits, $\mu$ is the overall mean of each trait, $A_{i}$ is the effect due to $i$ th age, $G_{j}$ is the fixed effect of $j$ th genotype, $(\mathrm{AG})_{i j}$ is the interaction between the $i$ th age and the $j$ th genotype, and $e_{i j k}$ is the random residual error.

\section{Results and discussion}

\subsection{Results of T-ARMS-PCR}

The T-ARMS-PCR method was successfully applied for genotyping of NRIPl c.605A $>\mathrm{G}$ and c. $1301 \mathrm{G}>\mathrm{A}$. The amount of inner to outer primers at a ratio of $5: 1$ was the most favorable in ensuring amplification efficiency and allele specificity. In addition, the use of touchdown PCR also permitted enhancement of the amplification of the allele-specific fragments and reduced artificial products (Li et al., 2014). To verify the accuracy of genotyping by T-ARMS-PCR, we also performed forced PCR-RFLP in all samples (Table 2). The concordance of these two SNPs between the two different methods was very high, indicating its reliability in SNP genotyping. 
Table 2. PCR primers for genetic variants identified in the bovine NRIPI gene.

\begin{tabular}{|c|c|c|c|c|c|c|c|}
\hline $\mathrm{SNPs}^{\mathrm{a}}$ & Variant types & Mutation types & $\begin{array}{l}\text { Genotyping } \\
\text { methods }\end{array}$ & $\begin{array}{l}\text { Restriction } \\
\text { enzyme }\end{array}$ & & Sequences of primers ${ }^{\mathrm{b}}(\mathrm{F} / \mathrm{R})$ & Genotype pattern (bp) \\
\hline \multirow[t]{6}{*}{ SNP1 } & \multirow[t]{6}{*}{ c. $605 \mathrm{~A}>\mathrm{G}$} & \multirow[t]{6}{*}{ Missense } & \multirow[t]{4}{*}{ T-ARMS-PCR } & & \multirow[t]{2}{*}{ Outer } & F: AGCGGAAGAGGCTGTCTGATTCCATC & \\
\hline & & & & & & R: ATAGCCTGCATTTTTGGGGGAAGAAG & $791 \mathrm{bp}$ (outer) $501 \mathrm{bp}(\mathrm{G})$ \\
\hline & & & & & \multirow[t]{4}{*}{ Inner } & F: GCTAAAGATCAAAAGCCCGATACAAG & 341 bp (A) \\
\hline & & & & & & R: AAGGGTTTTCGTGACATCAGGGAGGT & \\
\hline & & & PCR-RFLP & Alu I & & F: CCTAAAGGCAAACAGGACAGCA & $205 / 183+22^{\mathrm{C}}$ bp \\
\hline & & & & & & R: GGTTTTCGTGACATCAGGGAAG & $205 / 183+22$ bp \\
\hline \multirow[t]{6}{*}{ SNP2 } & \multirow[t]{6}{*}{ c. $1301 \mathrm{G}>\mathrm{A}$} & \multirow[t]{6}{*}{ Silent } & T-ARMS-PCR & & \multirow[t]{2}{*}{ Outer } & F: CTGGAAAGAAACAATATAAAACAGGC & \\
\hline & & & & & & R: ACTGAACGTGGCCGAGTTTTGTGCAC & 783 bp (outer) 597 bp (A) \\
\hline & & & & & \multirow[t]{4}{*}{ Inner } & F: AGCAGTGGCGATGAAAGTTCTTAATT & 237 bp (G) \\
\hline & & & & & & R: AGACAAGTCTATGGGAACACAGTGGG & \\
\hline & & & PCR-RFLP & Hinf I & & F: GCAGTGGCGATGAAAGTTCTGACT & $154 / 133+21^{\mathrm{c}} \mathrm{bp}$ \\
\hline & & & & & & R: TCAACTTCGGGGACTTTTGGA & $154 / 155+21$ op \\
\hline
\end{tabular}

a SNPs: single-nucleotide polymorphisms. ${ }^{\text {b }}$ Specificity is increased by the introduction of a deliberate mismatch at position -2 of the polymorphism site, indicated by underlined letters, and the framed base shows that the mismatch changes for creating restriction sites. ${ }^{\mathrm{c}}$ The pattern size was too short to be visible in the gel.

Table 3. Genetic diversity at Alu I and Hinf I locus of the bovine NRIP1 gene.

\begin{tabular}{|c|c|c|c|c|c|c|c|c|c|c|}
\hline \multirow[t]{2}{*}{ Locus } & \multirow[t]{2}{*}{ Breeds $^{\mathrm{a}}$} & \multicolumn{3}{|c|}{ Genotypic frequency } & \multicolumn{2}{|c|}{ Allelic frequency } & \multirow[t]{2}{*}{$H e^{\mathrm{b}}$} & \multirow[t]{2}{*}{$N e^{\mathrm{c}}$} & \multirow[t]{2}{*}{$\mathrm{PIC}^{\mathrm{d}}$} & \multirow[t]{2}{*}{ HWE $P$ value $\mathrm{e}^{\mathrm{e}}$} \\
\hline & & AA & AG & GG & A & G & & & & \\
\hline \multirow[t]{9}{*}{ SNP1 } & QC & 0.113 & 0.287 & 0.600 & 0.257 & 0.743 & 0.382 & 1.617 & 0.309 & $<0.05$ \\
\hline & NY & 0.067 & 0.100 & 0.833 & 0.117 & 0.883 & 0.206 & 1.260 & 0.185 & $<0.05$ \\
\hline & LX & 0.300 & 0.400 & 0.300 & 0.500 & 0.500 & 0.500 & 2.000 & 0.375 & $>0.05$ \\
\hline & CRS & 0.050 & 0.150 & 0.800 & 0.125 & 0.875 & 0.219 & 1.280 & 0.195 & $<0.05$ \\
\hline & JX & 0.035 & 0.103 & 0.862 & 0.086 & 0.914 & 0.158 & 1.187 & 0.145 & $<0.05$ \\
\hline & $\mathrm{CH}$ & 0.040 & 0.080 & 0.880 & 0.080 & 0.920 & 0.147 & 1.173 & 0.136 & $<0.05$ \\
\hline & AGS & 0.018 & 0.056 & 0.926 & 0.046 & 0.954 & 0.088 & 1.097 & 0.084 & $<0.05$ \\
\hline & HSK & 0.046 & 0.227 & 0.727 & 0.159 & 0.841 & 0.268 & 1.365 & 0.232 & $<0.05$ \\
\hline & YAK & 0.000 & 0.107 & 0.893 & 0.054 & 0.946 & 0.101 & 1.113 & 0.096 & $<0.05$ \\
\hline \multirow[t]{9}{*}{ SNP2 } & $\mathrm{QC}$ & 0.000 & 0.044 & 0.956 & 0.022 & 0.978 & 0.043 & 1.044 & 0.042 & $<0.05$ \\
\hline & NY & 0.000 & 0.035 & 0.965 & 0.018 & 0.982 & 0.035 & 1.036 & 0.034 & $<0.05$ \\
\hline & LX & 0.000 & 0.087 & 0.913 & 0.044 & 0.956 & 0.083 & 1.091 & 0.080 & $<0.05$ \\
\hline & CRS & 0.000 & 0.034 & 0.966 & 0.017 & 0.983 & 0.033 & 1.034 & 0.033 & $<0.05$ \\
\hline & JX & 0.000 & 0.010 & 0.990 & 0.005 & 0.995 & 0.010 & 1.010 & 0.010 & $<0.05$ \\
\hline & $\mathrm{CH}$ & 0.000 & 0.015 & 0.985 & 0.008 & 0.992 & 0.015 & 1.015 & 0.015 & $<0.05$ \\
\hline & AGS & 0.000 & 0.026 & 0.974 & 0.013 & 0.987 & 0.025 & 1.026 & 0.025 & $<0.05$ \\
\hline & HSK & 0.000 & 0.012 & 0.988 & 0.006 & 0.994 & 0.012 & 1.012 & 0.012 & $<0.05$ \\
\hline & YAK & 0.000 & 0.000 & 1.000 & 0.000 & 1.000 & 0.000 & 1.000 & 0.000 & $<0.05$ \\
\hline
\end{tabular}

a Breeds: QC, Qinchuan cattle; NY, Nanyang cattle; LX, Luxi cattle; CRS, Chinese Red Steppe cattle; JX, Jiaxian cattle; CH, Chinese Holstein; AGS, Angus; HSK, Hasake; YAK, yak. ${ }^{\mathrm{b}} \mathrm{He}$ : expected heterozygosity. ${ }^{\mathrm{c}} \mathrm{Ne}$ : effective allele numbers. ${ }^{\mathrm{d}}$ PIC: polymorphism information content. ${ }^{\mathrm{e}}$ HWE $P$ value: Hardy-Weinberg equilibrium $P$ value.

\subsection{Genetic diversity analyses}

Genetic indices (He, Ne and PIC) in these nine cattle populations are presented in Table 3. The observed $\mathrm{He}$ values ranged from 0.000 to 0.500 , while $\mathrm{Ne}$ values ranged from 1.000 to 2.000 . The minimum and maximum PIC values were 0.000 and 0.375 , respectively. The frequency of genotype GG (allele G) was dominant in all tested populations, although only the LX cattle in SNP1 was in HardyWeinberg equilibrium $(P>0.05)$. The $\chi^{2}$ test showed that the genotype distributions within other cattle populations were deviated from HWE $(P<0.05)$ (Table 3$)$, which indi- cates that there was no dynamic equilibrium even in artificial selection, migration, and genetic drift function. According to the classification of PIC (PIC value $<0.25$, low polymorphism; $0.25<$ PIC value $<0.5$, intermediate polymorphism; $0.5<$ PIC value, high polymorphism), in SNP1, the QC and LX breeds possessed intermediate polymorphism and the other seven breeds possessed low polymorphism. Compared with yellow cattle, genotype AA was not found in YAK, and the A allele frequency was very low, implying that this mutation is possibly associated with some quantitative traits $(\mathrm{Li}$ et al., 2014). In the other six cattle breeds, genotype GG was predominant, with frequencies ranging from 0.600 to 0.926 . 
Table 4. Significant associations of SNP at c.605A $>$ G locus with growth traits in Nanyang cattle.

\begin{tabular}{lrrrr}
\hline \multirow{2}{*}{ Age } & Growth traits & \multicolumn{3}{c}{ SNP genotypes (mean \pm SE) } \\
\cline { 3 - 5 } & & AA & GG & AG \\
\hline \multirow{2}{*}{ Birth } & BW $(\mathrm{kg})$ & $29.52 \pm 0.51$ & $29.85 \pm 0.64$ & $29.73 \pm 0.38$ \\
\hline \multirow{2}{*}{ months } & BW $(\mathrm{kg})$ & $155.03 \pm 3.69$ & $137.13 \pm 6.78$ & $156.35 \pm 2.54$ \\
& ADG $(\mathrm{kg})$ & $0.69 \pm 0.02$ & $0.59 \pm 0.04$ & $0.70 \pm 0.01$ \\
\hline \multirow{2}{*}{12 months } & BW $(\mathrm{kg})$ & $220.66 \pm 4.03$ & $210.87 \pm 7.41$ & $224.88 \pm 2.78$ \\
& ADG $(\mathrm{kg})$ & $0.36 \pm 0.02$ & $0.41 \pm 0.04$ & $0.38 \pm 0.02$ \\
\hline \multirow{2}{*}{18 months } & BW $(\mathrm{kg})$ & $304.25 \mathrm{ab} \pm 2.21$ & $295.47 \mathrm{a} \pm 3.15$ & $324.20 \mathrm{~b} \pm 12.18$ \\
& ADG $(\mathrm{kg})$ & $0.47 \mathrm{ab} \pm 0.04$ & $0.40 \mathrm{a} \pm 0.02$ & $0.60 \mathrm{~b} \pm 0.11$ \\
\hline
\end{tabular}

Mean \pm SE: means \pm standard error of means. Letters a and b denote values that differ significantly at $P<0.05$. BW: body weight; ADG: average daily gain.

This means that GG has existed for a long time and is more adapted to steppe environments (Huang et al., 2011). For SNP2, all nine breeds possessed low polymorphism. Genotypes AG and GG were detected and genotype GG was predominant in all nine cattle breeds, with frequencies ranging from 0.913 to 1.000 . Interestingly, only genotype GG was found in YAK, which might result from a specific selection history and/or a smaller sample size.

\subsection{Association analyses in NY cattle}

The results of the association analyses between single markers and growth traits (body weight and average daily gain) are shown in Table 4. The other recorded growth traits (body height, body length, heart girth, and hucklebone width) were not significantly associated with genotypes $(P>0.05$; data not shown).

Among these two loci, c.605A $>\mathrm{G}$ significantly associated with body weight $(P<0.05)$ and average daily gain $(P<0.05)$ at 18 months between cattle with genotypes AG, AA, and GG. Individuals with genotype AG appeared to be superior in body weight and average daily gain at 18 months compared with those with genotype AA, which indicates that the heterozygosis of this locus was associated with an increase in these two traits at 18 months in the population. Strangely, the highest performance appeared in heterozygotes, so there may not be any additive effects. Therefore, it may be the interactions between other effects that caused the heterozygotes to have highest performance; this requires further study. This SNP is located in the CDS region of the bovine NRIP1, which resulted in a missense mutation, Asn $>$ Ser. Growth traits are physiological functions that are controlled by multiple genes. Genes proven to have significant correlation with related traits could be candidates in the successful application of MAS. When used in practice, the positive-effect genes should be chosen simultaneously as molecular markers. Previous work has demonstrated that NRIP1 plays an important role in regulating the expression of clusters of genes in many metabolism pathways (Powelka et al., 2006), so NRIPl could be an important candidate gene for the study of growth traits.

In conclusion, two novel polymorphisms (c.605A>G and c. $1301 \mathrm{G}>\mathrm{A}$ ) in the bovine NRIP1 gene were detected in this study using T-ARMS-PCR, which is a rapid and costeffective method; this implies that T-ARMS-PCR is a reliable method for genotyping. In addition, the SNP c.605A>G was demonstrated to have a significant association with body weight and average daily gain of NY cattle at 18 months of age. These findings will be of benefit for cattle breeding and genetics.

Acknowledgements. This study was supported by the National Natural Science Foundation of China (grant no. 31272408), the Program of National Beef Cattle Industrial Technology System (CARS-38), and the National 863 Program of China (grant no. 2013AA102505).

Edited by: K. Wimmers

Reviewed by: two anonymous referees

\section{References}

Catalán, V., Gómez-Ambrosi, J., Lizanzu, A., Rodríguez, A., Silva, C., Rotellar, F., Gil, M. J., Cienfuegos, J. A., Salvador, J., and Frühbeck, G.: RIP140 gene and protein expression levels are down-regulated in visceral adipose tissue in human morbid obesity, Obes. Surg., 19, 771-776, 2009.

Docquier, A., Harmand, P. O., Fritsch, S., Chanrion, M., Darbon, J. M., and Cavaillès, V.: The transcriptional coregulator RIP140 represses E2F1 activity and discriminates breast cancer subtypes, Clin. Cancer Res., 16, 2959-2970, 2010.

Fritah, A., Steel, J. H., Nichol, D., Parker, N., Williams, S., Price, A., Strauss, L., Ryder, T. A., Mobberley, M. A., Poutanen, M., Parker, M., and Roger, W.: Elevated expression of the metabolic regulator receptor-interacting protein 140 results in cardiac hypertrophy and impaired cardiac function, Cardiovasc. Res., 86, 443-451, 2010. 
Herzog, B., Hallberg, M., Seth, A., Woods, A., White, R., and Parker, M. G.: The nuclear receptor cofactor, receptor-interacting protein 140, is required for the regulation of hepatic lipid and glucose metabolism by liver X receptor, Mol. Endocrinol, 21, 2687-2697, 2007.

Huang, Y. Z., He, H., Sun, J. J., Wang, J., Li, Z. J., Lan, X. Y., Lei, C. Z., Zhang, C. L., Zhang, E. P., Wang, J. Q., and Chen, H.: Haplotype combination of SREBP-1c gene sequence variants is associated with growth traits in cattle, Genome, 54, 507-516, 2011.

Li, M. X., Sun, X. M., Jiang, J., Sun, Y. J., Lan, X. Y., Lei, C. Z., Zhang, C. L., and Chen, H.: Tetra-primer ARMS-PCR is an efficient SNP genotyping method: An example from SIRT2, Anal. Methods, 6, 1835-1840, 2014.

Nei, M.: Analysis of gene diversity in subdivided populations, P. Natl. Acad. Sci. USA, 70, 3321-3323, 1973.

Nichol, D., Christian, M., Steel, J. H., White, R., and Parker, M. G.: RIP140 expression is stimulated by estrogen-related receptor alpha during adipogenesis, J. Biol. Chem., 281, 32140-32147, 2006.

Powelka, A. M., Seth, A., Virbasius, J. V., Kiskinis, E., Nicoloro, S. M., Guilherme, A., Tang, X., Straubhaar, J., Cherniack, A. D., Parker, M. G., and Czech, M. P.: Suppression of oxidative metabolism and mitochondrial biogenesis by the transcriptional corepressor RIP140 in mouse adipocytes, J. Clin. Invest., 116, 125-136, 2006.
Rincon, G. and Medrano, J. F.: Single nucleotide polymorphism genotyping of bovine milk protein genes using the tetra-primer ARMS-PCR, J. Anim. Breed. Genet., 120, 331-337, 2003.

Sambrook, J. and Russell, D. W.: Molecular cloning: a laboratory manual, 3rd edn., Vol. 3, Cold Spring Harbor Laboratory Press, New York, 2001.

Seth, A., Steel, J. H., Nichol, D., Pocock, V., Kumaran, M. K., Fritah, A., Mobberley, M., Ryder, T. A., Rowlerson, A., Scott, J., Poutanen, M., White, R., and Parker, M.: The transcriptional corepressor RIP140 regulates oxidative metabolism in skeletal muscle, Cell Metab., 6, 236-245, 2007.

Steel, J. H., White, R., and Parker, M. G.: Role of the RIP140 corepressor in ovulation and adipose biology, J. Endocrinol., 185, 19, 2005

White, R., Leonardsson, G., Rosewell, I., Ann-Jacobs, M., Milligan, S., and Parker, M.: The nuclear receptor co-repressor NRIPI (RIP140) is essential for female fertility, Nat. Med., 6, 13681374, 2000.

Ye, S., Dhillon, S., Ke, X., Collins, A. R., and Day, I. N.: An efficient procedure for genotyping single nucleotide polymorphisms, Nucleic. Acid. Res., 29, 88-95, 2001. 